Energy Research Journal 1 (1): 12-21, 2010

ISSN 1949-0151

(C) 2010 Science Publications

\title{
Pre-Feasibility Study of Hybrid Hydrogen Based Energy Systems for Coastal Residential Applications
}

\author{
${ }^{1}$ Mohd Zamri Ibrahim, ${ }^{1}$ Roziah Zailan, ${ }^{1}$ Marzuki Ismail and ${ }^{2}$ Abdul Majeed Muzathik \\ ${ }^{1}$ Department of Engineering Science, Faculty of Science and Technology, \\ University Malaysia Terengganu, 21030 Kuala Terengganu, Malaysia \\ ${ }^{2}$ Department of Maritime Technology, Faculty of Maritime Studies and Marine Science, \\ University Malaysia Terengganu, 21030 Kuala Terengganu
}

\begin{abstract}
Problem statement: The purpose of this study is to design a renewable energy hydrogen based power system to provide electricity to a coastal residential area in east coast area (Kuala Terengganu) of Malaysia. Approach: The selected case study represents a power demand of $20 \mathrm{kWh} \mathrm{day}^{-1}$. The autonomous system used in this study is diesel generator, wind and photovoltaic hybrid system. The power system was redesigned and optimized as hydrogen-based autonomous power systems in order to meet the existing user's power demand at a minimum cost of energy. Wind speed and solar radiations data obtained from Malaysian Meteorological Department have been used in the simulation process through optimization software, Hybrid Optimization Model for Electric Renewables (HOMER). Results: Three systems that were considered in this study area are stand alone PV-wind-diesel, stand alone PV-wind-hydrogen and grid connected PV-wind-hydrogen energy system. The proposed systems then were compared regarding on their operational characteristics and cost values. The comparisons prove that grid connected PV-wind-hydrogen energy system had the lowest total net present cost and cost of energy, $\$ 53,197$ and $\$ 0.57 / \mathrm{kWh}$, respectively that makes it the most cost effective system and followed by PV-wind-diesel and stand alone PV-wind-hydrogen system. Conclusion/Recommendations: It can be concluded that the hydrogen-based system can become a favorable system without aid from the grid system and bring advantage in technical and economic point of view and also suitable to be applied in the coastal residential application as energy carrier if only the current cost of wind turbine, PV arrays and hydrogen system technology have been reduced to its minimum rate.
\end{abstract}

Key words: Cost of energy, HOMER, Hydrogen based power system, Kuala Terengganu, net present cost

\section{INTRODUCTION}

At present, renewable energy based low-emission hybrid energy systems with hydrogen storage are not cost-competitive against conventional fossil fuel based stand-alone or grid interfaced power systems. However, the need for cleaner power and improvements in alternative energy technologies bear good potential for widespread use of such systems (Khan and Iqbal, 2005). Various energy sources (wind, solar, diesel generator) and storage systems (battery, electrolyzerhydrogen tank) were normally considered in such analysis. In these studies the National Renewable Energy Laboratory's (NREL) optimization tool "HOMER" was used in identifying probable hybrid configurations and their applicability.
Zoulias and Lymberopoulos (2007) examine the techno-economic aspects of replacing diesel generators and batteries of the system by hydrogen system as well as present the sizing optimisation and simulation results of both systems. The results of the analyses also showed that the replacement of fossil fuel generator set with hydrogen technologies is technically feasible, but still not economically viable until reductions in the cost of hydrogen technologies are made in the future.

Khan and Iqbal (2005) also conducted a prefeasibility study of using hybrid energy systems with hydrogen as an energy carrier for applications in Newfoundland, Canada was established using HOMER. A remote house having an energy consumption of $25 \mathrm{kWh} \mathrm{day}^{-1}$ and $4.73 \mathrm{~kW}$ peak power demands was

Corresponding Author: Mohd Zamri Ibrahim, Department of Engineering Science, Faculty of Science and Technology, University Malaysia Terengganu, 21030 Kuala Terengganu, Malaysia

Tel: +6096683328/ext 3328 Fax: + 6096694660 
considered as the stand-alone load. It was found that, a wind-diesel-battery hybrid system is the most suitable solution at present. However, a wind-fuel cell system would be a more attractive choice if the fuel cell cost reduces to $15 \%$ of its present market price. Significant advancement in small wind turbine technology and fuel cell research is needed before a wind-fuel cell system could be termed as commercially feasible.

This kind of research through HOMER model has also been experienced in Malaysia (Goh and Barsoum, 2006). The aim was to design the aspects of a hybrid power system of photovoltaic panels with the fuel cell and secondary batteries as backup units that will provide electricity for a small and remote located community. The accentuation on the hydrogen hybrid power system is exactly to obtain a reliable autonomous system with the optimization of the components size and the improvement of the capital cost. The results conclude that the replacement of the conventional system by a PEM fuel cell can keep the system reliability of supply at the same level while decreasing the environmental impact of the whole system.

The present study is proposed to design a hydrogen based power system to provide electricity for a coastal residential area in Kuala Terengganu, Malaysia (Fig. 1). The selected case study, which is being operating represent a power demand of $20 \mathrm{kWh}$ day $^{-1}$ and peak demand of $3.1 \mathrm{~kW}$. The autonomous system used in this study is diesel generator-PV-wind system that right through upgraded to a standalone PV-wind-hydrogen and grid connected PV-wind-hydrogen energy system.

Hence, the rationale of this study is to examine the feasibility of integrating the hydrogen energy technologies in existing autonomous power system taking into consideration of technical and economic

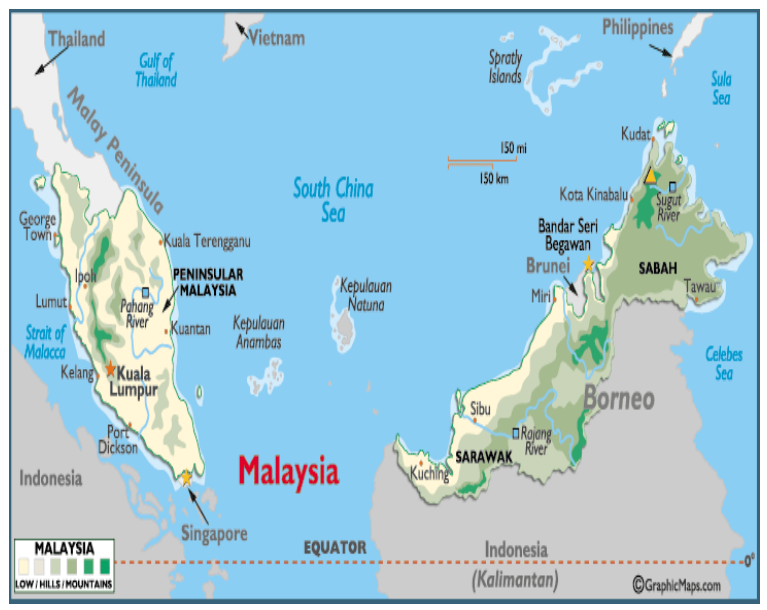

Fig. 1: Location of the research area aspects. The system simulation performed is to estimate its operational characteristics, such as annual electricity production, annual loads served, excess electricity and capacity shortage. The proposed systems then was compared concerning on their operational characteristics and cost value in order to meet the existing user's power demand at a minimum cost of energy.

\section{MATERIALS AND METHODS}

\section{Energy demand and resources:}

Electrical load: Electrical load is one or more devices that consume electric energy. While, electricity demand is the rate at which electric energy is required by the load, measured in kilowatts $(\mathrm{kW})$ (Demiroren and Yilmaz, 2010). The data were measured for the total hourly basis daily electrical load requirement of a residential of a small coastal village in Kuala Terengganu. The electrical load components include fluorescent lamps, ceiling fan, television, refrigerator and also washing machine which are the main components for a small house. The hourly load consumed by the house is presented in Fig. 2.

Solar radiation resources: Hourly solar radiation data for year 2006 was collected from Malaysian Meteorological Department (MMD). Using this data the monthly average daily solar radiation shown in Fig. 3 and long-term average annual solar radiation $\left(1.28 \mathrm{kWh} \mathrm{m}^{-1} \mathrm{day}^{-1}\right)$ were calculated for Kuala Terengganu. From the latitude information and solar radiation of the site under investigation, the HOMER software calculated the clearness index (a measure of the clearness or cloudiness of the atmosphere) shown in Fig. 3.

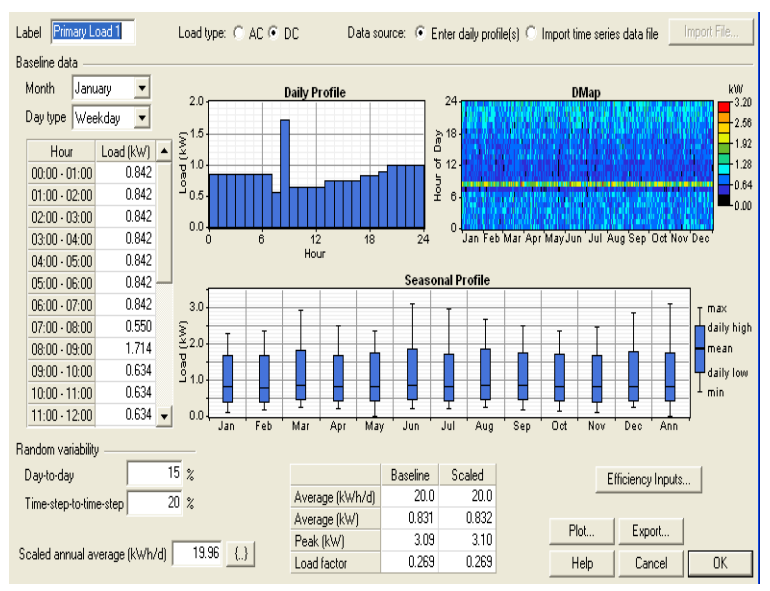

Fig. 2: Hourly load consumption for a house 


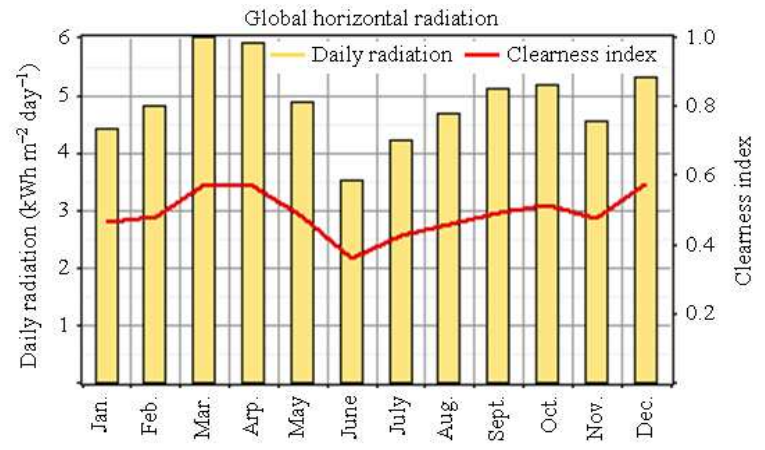

Fig. 3: Monthly average daily radiation and clearness index

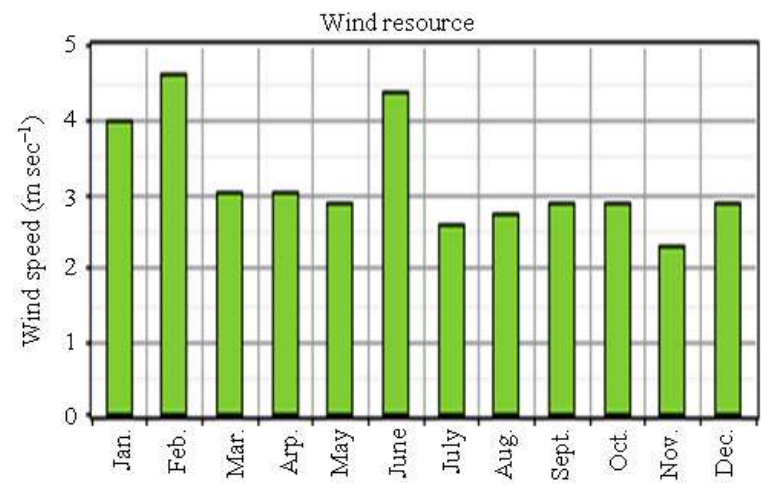

Fig. 4: Monthly average wind speed

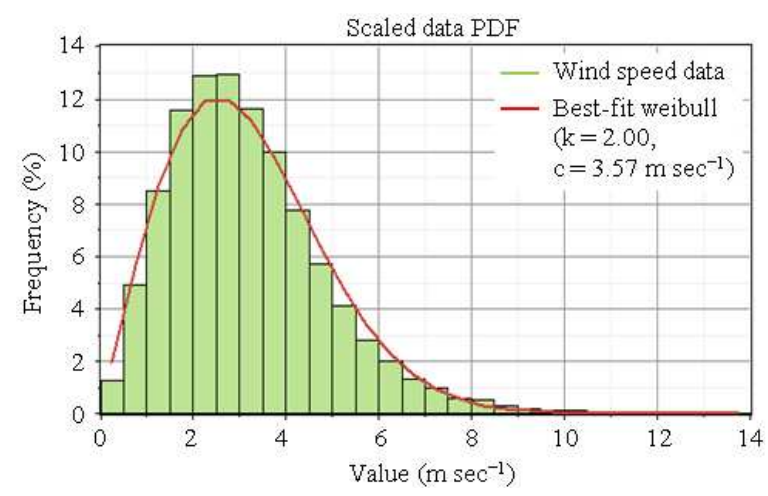

Fig. 5: Wind speed probability distribution

Wind resources: Hourly wind speed data for year 2006 also was collected from MMD and from this data the monthly average wind speeds were calculated, which, are shown in Fig. 4. It indicates that the annual average wind speed at hub height of $50 \mathrm{~m}$ in Kuala Terengganu is $3.16 \mathrm{~m} \mathrm{sec}^{-1}$. Figure 4 shows that in May to November except June, the wind speeds are lower than the annual average wind speed. The higher wind speed during the monsoon season explained these conditions.

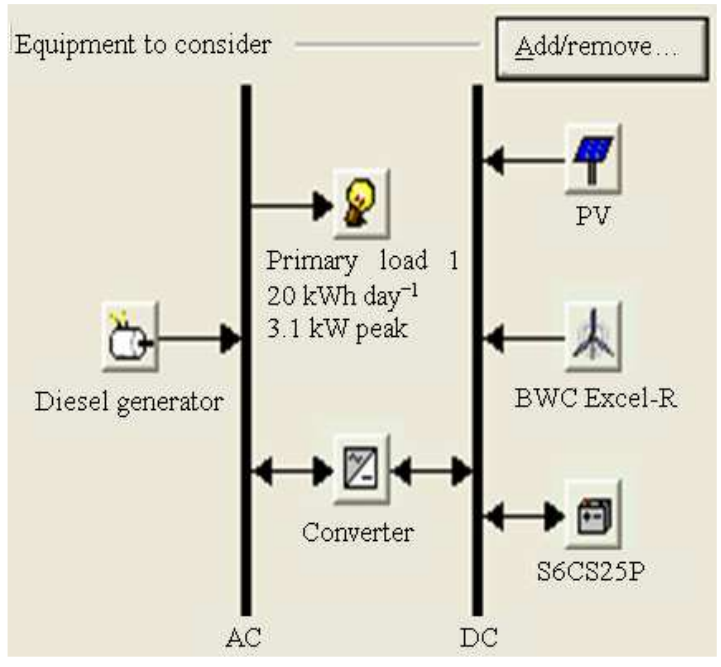

Fig. 6: PV-wind-diesel power system components

The wind data was analyzed using the Weibull distribution. The results show that the Weibull shape factor, $\mathrm{k}$ is 2.0 and scale factor, $\mathrm{c}$ is $3.57 \mathrm{~m} \mathrm{sec}^{-1}$. The autocorrelation factor (randomness in wind speed) is found to be 0.85 . The diurnal pattern strength (wind speed variation over a day) is 0.25 (Fig. 5).

PV-wind-diesel power system: The schematic diagram of Photovoltaic (PV)-wind-diesel power system components are presented in Fig. 6. The energy system consists of diesel generator, PV arrays, wind turbine, battery and power converters. The cost, number of units to be used, capacity, operating hours and other specifications are needed to run the simulation using HOMER software. The details of the system components were obtained from manufacturers of the equipments and previous studies (Khan and Iqbal, 2005; Zoulias and Lymberopoulos, 2007; Goh and Barsoum, 2006; Demiroren and Yilmaz, 2010; Dalton et al., 2009; Bergey Wind Power, 2009; Australian Government, 2009). The descriptions of these components are given below.

Diesel generator: The cost of a commercially available diesel generator may vary from $\$ 250-\$ 500 \mathrm{~kW}^{-1}$ (Dalton et al., 2009). For larger units per $\mathrm{kW}$ cost is lower and smaller units cost more. The $5 \mathrm{~kW}$ diesel generator at cost $\$ 450$ was being used as the peak power demand is less than $5 \mathrm{~kW}$. Replacement and operational costs are assumed to be $\$ 400$ and $\$ 0.150 \mathrm{~h}^{-1}$, respectively. While, the lifetime is $15000 \mathrm{~h}$. In this study no diesel generator $(0 \mathrm{~kW})$ or a $5 \mathrm{~kW}$ unit were used for simulation by HOMER. 


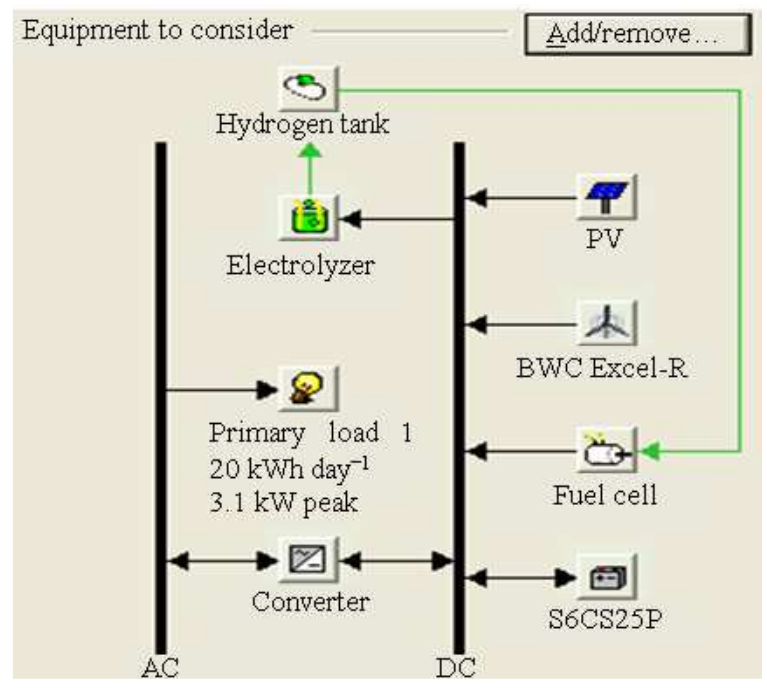

Fig. 7: Standalone PV-wind-hydrogen power system components

PV-array: The installation cost of PV arrays may vary from $\$ 6.00-\$ 10.00 / \mathrm{W}$. A $1 \mathrm{~kW}$ solar energy system installation and replacement costs are taken as $\$ 7000$ and \$6000, respectively (Dalton et al., 2009). Various sizes were considered, ranges from $0-6 \mathrm{~kW}$ in this study. The lifetime of the PV arrays are taken as 20 years and no tracking system was included in the PV system.

Wind turbine: Availability of energy from the wind turbine depends greatly on wind variations. Therefore, wind turbine rating is generally much higher compared to the average electrical load. In this analysis, Bergey wind power's BWC Excel-R model was considered. It has a rated capacity of $8.1 \mathrm{~kW}$ and provides $48 \mathrm{~V}$ DC as output. Cost of one unit was considered to be $\$ 19,400$ while replacement and maintenance costs were taken as $\$ 15,000$ and $\$ 75$ year $^{-1}$ respectively (Bergey Wind Power, 2007). To allow the simulation program hit an optimum solution, provision for using several units $(0$, $12,24,26,28,30$ and 32) were considered for the study location. The lifetime of the turbine was taken as 20 years.

Batteries: Batteries are considered as a major cost factor in small-scale stand-alone power systems. A battery bank of commercially available units, surrette-6CS25P model (6 V, $1156 \mathrm{Ah}$ and $9645 \mathrm{~kW}$ ) (Khan and Iqbal, 2005) was considered in this simulation. The estimated lifetime is 5 years and the cost of one battery is $\$ 1250$ with a replacement cost of $\$ 1100$ while the $\mathrm{O}$ and $\mathrm{M}$ cost is $\$ 0.02$ year $^{-1}$ were considered for this study. The battery stacks may contain a number of batteries range from 0 125 units.

Power converter: A power electronic converter needs to maintain flow of energy between the ac and dc components. For a $1 \mathrm{~kW}$ system the installation and replacement costs were taken as $\$ 800$ and $\$ 750$, respectively. Four different sizes of converters $(0,2,5$ and $7 \mathrm{~kW}$ ) were considered for the simulation. Lifetime of a unit was considered to be 15 years with an efficiency of $90 \%$.

Stand alone PV-wind-hydrogen power system: Subsequently, the conventional hybrid energy system has been upgraded to hybrid system of standalone PVwind-hydrogen energy system that schematically designs as in Fig. 7. All the meteorological data that were used are same as the previous simulation.

The equipments needed to build the system are PV array, wind turbine, battery, fuel cell, electrolyzer, hydrogen tank and power electronic converters. In this hybrid energy system also, the type of wind turbine and battery were used same as the previous system, which are BWC Excel-R and Surrette 6CS25P, respectively. But different sizes were selected in order to define optimum combination of equipment dimensions. Stand alone PV-wind hydrogen system components are described more detail below.

PV-array: For this stand alone hybrid system, the PV capital, replacement and $\mathrm{O}$ and $\mathrm{M}$ costs, as well as component lifetime described under 3.2 were used. The considered sizing range from $0-40 \mathrm{~kW}$.

Wind turbine: In the optimization process, the costs of the wind turbine were the same as the one used in previous energy system. The quantity of wind turbines considered for this systems were $0,1,2,24,26,30$ and 32 units.

Electrolyzer: Currently production cost of electrolyzers is $\$ 1500-\$ 3000 \mathrm{~kW}^{-1}$. With improvements in polymer technology, control systems and power electronics it is expected that costs would reduce much in 10 years (Dalton et al., 2009). In this analysis, various sizes of electrolyzers $(0-50 \mathrm{~kW})$ were considered. A $1 \mathrm{~kW}$ system is associated with $\$ 2000$ capital, \$1500 replacement and \$20 maintenance cost. Lifetime is considered as 25 years with efficiency $75 \%$.

Power converter: Power electronic converter description is similar as describe above. For a $1 \mathrm{~kW}$ system the installation and replacement costs are taken 
as $\$ 800$ and $\$ 750$, respectively. Three different sizes of converter $(1.5,3.5$ and $5 \mathrm{~kW})$ were taken in the model.

Fuel cell system: The cost of fuel cell varies greatly depending on type of technology, reformer, auxiliary equipments and power converters. At present, a fuel cell cost varies from $\$ 3000-\$ 6000 \mathrm{~kW}^{-1}$ (Dalton et al., 2009). Here, the capital, replacement and operational costs were taken as $\$ 3000, \$ 2500$ and $\$ 0.020 / \mathrm{h}$ for a 1 $\mathrm{kW}$ system, respectively. Five different sizes of fuel cells were taken in the simulation process: 0 (no fuel cell used), 1.5, 3.5 and $5 \mathrm{~kW}$. Fuel cell lifetime and efficiency were considered to be $40,000 \mathrm{~h}$ and $50 \%$, respectively.

Hydrogen tank: Cost of a tank with $1 \mathrm{~kg}$ of hydrogen capacity was assumed to be $\$ 1300$. The replacement and operational costs were taken as $\$ 1200$ and $\$ 15$ year $^{-1}$, respectively. Seven different sizes $(0,1,2.5,3,7.5,10$ and $15 \mathrm{~kg}$ ) were included, to widen the search space for a cost effective configuration and the lifetime was also considered as 25 years.

Grid connected PV-wind-hydrogen power system: Afterward, the grid-connected PV-wind-hydrogen analysis has been done to review the ability of electricity production from the renewable sources, photovoltaic and wind. In this system electricity from the grid was used to supply power to the electrolyzer device in order to produce hydrogen during the deficient in power from PV and wind. The schematic design appears in Fig. 8.

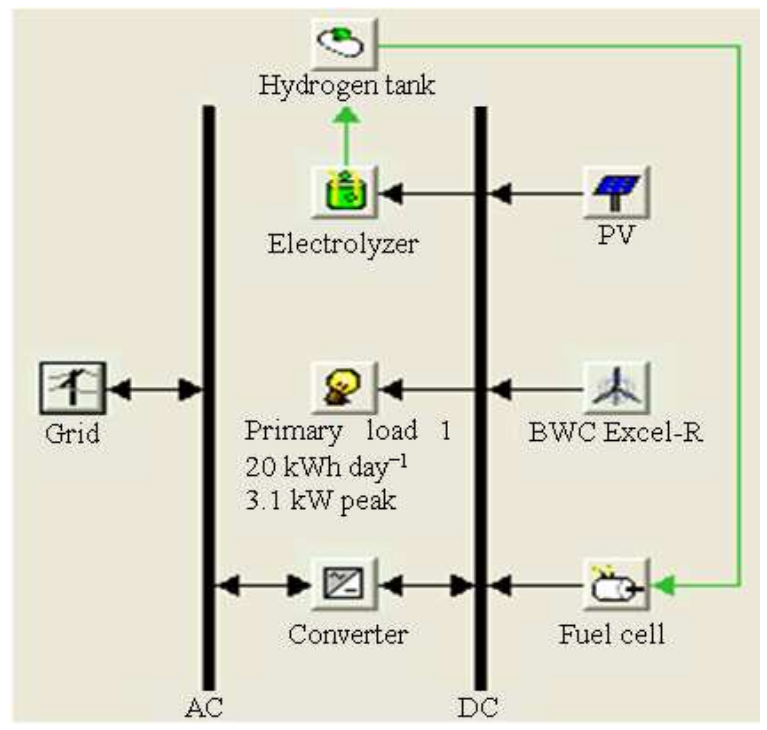

Fig. 8: Grid connected PV-wind hydrogen power system components
Such system forms of the similar equipments as standalone PV-wind-hydrogen that mentioned before. Except, the power transmission or grid system was attached. The single rate that refers to the fix power price, sellback rate and demand rate was set for the case of residential consumers. The fix power is $0.1 \$ \mathrm{kWh}^{-1}$ while the sellback rate and demand rate are $0.05 \$ \mathrm{kWh}^{-1}$ and $0.00 \$ \mathrm{kWh}^{-1} \mathrm{month}^{-1}$, respectively.

The grid system works in two conditions. When the renewable energy system produces more power that the house needs, the excess power is fed back into the grid. However, when the does not produce enough power, then the power can be drawn from the grid.

\section{RESULT AND DISCUSSION}

PV-wind-diesel system simulation: For hybrid PVwind-diesel energy system, the equipments needed to build the system were diesel generator, PV array, wind turbine, batteries and power electronic converter with the type and quantity that mentioned before. The HOMER simulation tool was used to optimize the sizes of different hardware components in the PV-winddiesel system, taking into account the technical characteristics of system operation and minimizing total net present cost of the system. The simulation of the system completed with in $1 \mathrm{~min}$. The optimization results of this power system are show in Fig. 9.

The least Cost Of Energy (COE), $\$ 0.74 \mathrm{kWh}^{-1}$ resulted from the $5 \mathrm{~kW}$ diesel generator alone without contribution from renewable sources. If considered the system, which is included the renewable energies is fifteenth least COE as $\$ 0.90 \mathrm{kWh}^{-1}$, resulted from the combination of $5 \mathrm{~kW}$ diesel generator, $0.25 \mathrm{~kW}$ of PV array, 1 unit of wind turbine, 12 unit of batteries and $2 \mathrm{~kW}$ converter. The diesel used for first system is 4,177 L, while the second system is $2,928 \mathrm{~L}$. Consequently, the consumption of diesel fuel can be reduced about $30.0 \%$ with involvement of renewable resources.

The distribution of annualized cost for each component of the hybrid PV-wind-diesel energy system is presented in Table 1.

The capital cost, total Net Present Value (NPC) and COE of the systems are $\$ 40,600, \$ 84,348$ and $\$ 0.90 \mathrm{kWh}^{-1}$ respectively. The most expensive cost draws from the diesel generator. Although the capital for the generator is just $\$ 450$, but the high cost of diesel fuel, $\$ 24,332$ sums it up to $\$ 30,427$. Wind turbine is in the second placed with the cost of $\$ 25,453$, followed by battery and converter with $\$ 22,001$ and $\$ 4,511$, respectively. The least cost device is PV-array that contributes $\$ 1,956$ to the overall system. The allocation of each device can be seen clearly from Fig. 10. 
Energy Rec. J. 1 (1): 12-21, 2010

Table 1: Annualized cost for main components of the PV-wind-diesel system

\begin{tabular}{|c|c|c|c|c|c|c|}
\hline Component & Capital (\$) & Replacement (\$) & $\mathrm{O}$ and $\mathrm{M}(\$)$ & Fuel (\$) & Salvage (\$) & Total (\$) \\
\hline PV & 1,750 & 468 & 0 & 0 & -262 & 1,956 \\
\hline Wind turbine & 19,400 & 6,259 & 959 & 0 & $-1,165$ & 25,453 \\
\hline Diesel generator & 450 & 739 & 4,970 & 24,332 & -63 & 30,427 \\
\hline Batteries & 15,000 & 9,820 & 0 & 0 & $-2,819$ & 22,001 \\
\hline Converter & 4,000 & 0 & 511 & 0 & 0 & 04,511 \\
\hline System & 40,600 & 17,285 & 6,440 & 24,332 & $-4,310$ & 84,348 \\
\hline
\end{tabular}

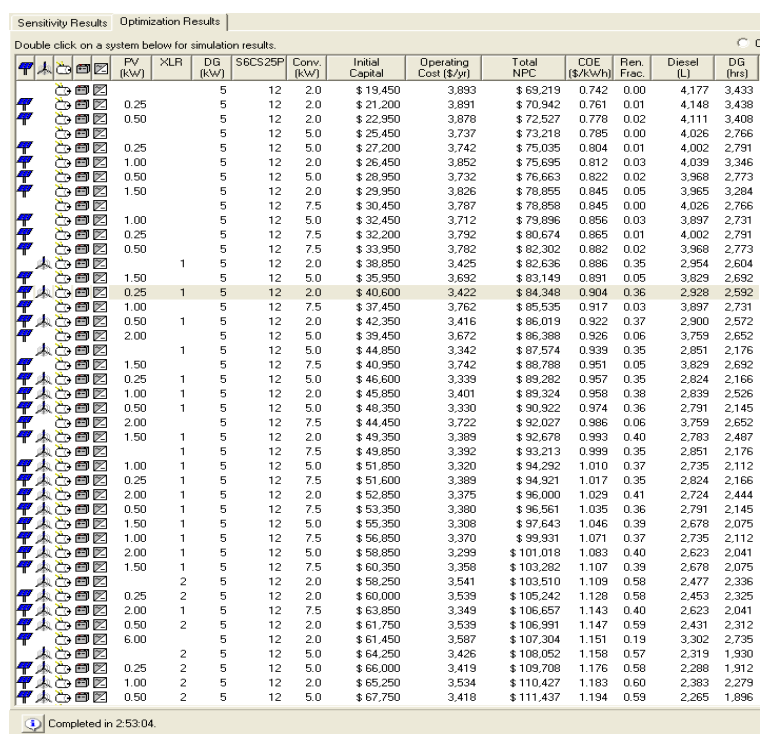

Fig. 9: The simulation results for PV-wind-diesel energy system

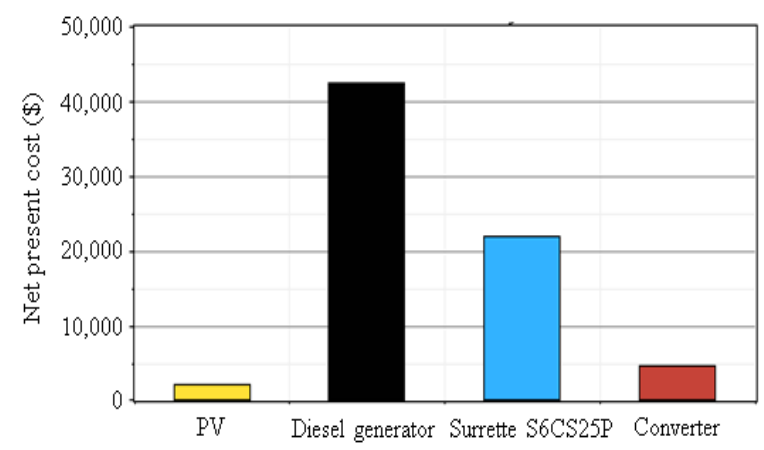

Fig. 10: Cost components of PV-Wind-Diesel System

The PV-wind-diesel hybrid system also simulated in order to evaluate its operational characteristics, namely annual electrical energy production, annual electrical load served, excess electricity, renewable energy fraction, capacity shortage and unmet load.

The strategy taken in this simulation is to ensure the power generator provide enough power to meet the demand. The renewable energy sources in collaboration
Table 2: Operational characteristics of the PV-wind-diesel hybrid system

\begin{tabular}{llr}
\hline Annual electricity production & $\mathrm{kWh} \mathrm{year}^{-1}$ & Percent \\
\hline PV-array & 87 & 1.00 \\
Diesel generator & 7,566 & 64.00 \\
Wind turbine & 4185 & 35.00 \\
Total production & 11,838 & 100.00 \\
Annual electrical load served & & \\
AC primary load served & 7,299 & 100.00 \\
Total & 7,299 & 100.00 \\
Other & & \\
Excess electricity & 1,129 & 9.82 \\
Unmet electric load & 0.543 & 0.01 \\
Capacity shortage & 1.17 & 0.02 \\
Renewable fraction & 0.361 & \\
\hline
\end{tabular}

with the diesel generator were evaluated to determine the feasibility of the system.

The values related to the electricity production and load served by the system are summarized in Table 2. The results of the simulation showed that the PV-winddiesel hybrid system had a total annual electrical energy production of $11,838 \mathrm{kWh}$ year $^{-1}$. The biggest contributor is diesel generator comprise of $63 \%$ equal to $7,566 \mathrm{kWh} /$ year. The renewable energy fraction is 0.361 . The contribution of renewable sources which come from PV-array and wind turbine produce 1\% (87 $\left.\mathrm{kWh}_{\text {year }}{ }^{-1}\right)$ and $35 \%\left(4,185 \mathrm{kWh}\right.$ year $\left.^{-1}\right)$, respectively. Besides that, it can be seen that approximately $9.82 \%$ (1144 kWh year $^{-1}$ ) was neglected. These excess energy can be manipulated to increase renewable energy penetration by stored it in the form of compressed hydrogen and drive a PEM fuel cell will be discussed in the standalone PV-wind hydrogen energy system.

The trend of monthly electricity production is shown in Fig. 11. The wind is highly potential in three months, January, February and June. Hence, diesel generator operated frequently in other months. The condition is occurs due to the high nighttime load, which enables the operation of diesel generator because wind and PV energy stored in batteries is not adequate to serve the load during night time.

Stand alone PV-wind-hydrogen system simulation: The design of stand-alone power systems with hydrogen energy involves different energy components sizes, with regards to the cost of energy and overall 


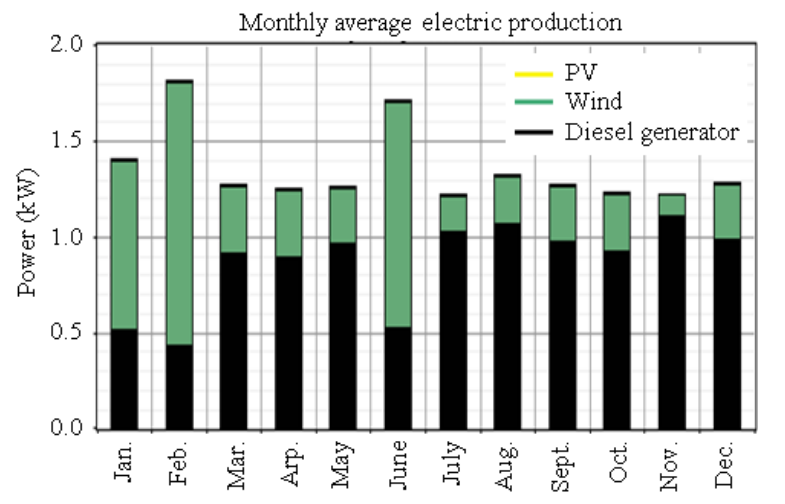

Fig. 11: Monthly electricity production trend of the system

\begin{tabular}{|c|c|c|c|c|c|c|c|c|c|c|c|}
\hline \multicolumn{12}{|c|}{ 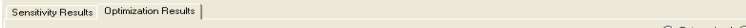 } \\
\hline 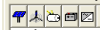 & & 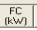 & & 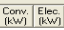 & 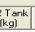 & $\begin{array}{l}\text { Ininial } \\
\text { Eopitat }\end{array}$ & 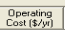 & $\begin{array}{c}\text { Todol } \\
\text { NFL }\end{array}$ & 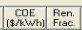 & 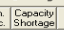 & 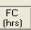 \\
\hline T1 圆 & $\frac{1}{6}$ & & $\frac{12}{12}$ & $\begin{array}{l}35 \\
35\end{array}$ & & 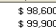 & $\begin{array}{l}1950 \\
1965\end{array}$ & $\begin{array}{l}\$ 123.532 \\
\$ 15251.54\end{array}$ & $\begin{array}{ll}1.330 & 7.00 \\
1.346 & 1.00 \\
1.00\end{array}$ & $\begin{array}{ll}0 \\
10 \\
10\end{array}$ & \\
\hline & 8 & & 12 & 5.0 & 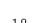 & 899.800 & 1,980 & $\$ 125,114$ & 1.347 1.00 & 0.01 & \\
\hline & $\begin{array}{c}5 \\
5\end{array}$ & & $\begin{array}{l}12 \\
12\end{array}$ & $\begin{array}{l}5.0 \\
3.5\end{array}$ & $\begin{array}{l}1.0 \\
2.5\end{array}$ & 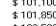 & 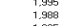 & 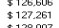 & $\begin{array}{l}1.364 \\
1.371 \\
1.000\end{array}$ & $\begin{array}{l}0.01 \\
0.01\end{array}$ & \\
\hline & 6 & & $\begin{array}{l}12 \\
12 \\
12\end{array}$ & $\begin{array}{c}3.5 \\
5,0 \\
35\end{array}$ & $\begin{array}{l}3.0 \\
2.5\end{array}$ & 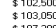 & $\begin{array}{l}1995 \\
2018 \\
2018\end{array}$ & 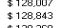 & $\begin{array}{ll}1.379 \\
1.380\end{array}$ & $\begin{array}{c}001 \\
001\end{array}$ & \\
\hline & 5 & & 12 & $\begin{array}{l}3.0 \\
5.0\end{array}$ & 3.0 & 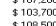 & 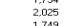 & 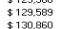 & $\begin{array}{l}1.389 \\
1.396 \\
1.000 \\
1.00\end{array}$ & $\begin{array}{l}0.01 \\
0.01\end{array}$ & \\
\hline & 10 & & $\begin{array}{ll}12 \\
12 \\
12\end{array}$ & $\begin{array}{l}3.5 \\
5.0 \\
50\end{array}-100$ & 1.0 & 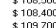 & $\begin{array}{l}1.749 \\
1.764 \\
1.779\end{array}$ & 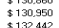 & 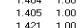 & 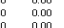 & \\
\hline & $\begin{array}{l}10 \\
10\end{array}$ & & $\begin{array}{l}12 \\
12 \\
12\end{array}$ & $\begin{array}{l}3.5 \\
3.5 \\
3.5\end{array}$ & $\begin{array}{l}2.0 \\
3.0\end{array}$ & 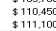 & $\begin{array}{l}1,772 \\
1,779\end{array}$ & 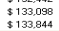 & $\begin{array}{lll}1.428 \\
1.00 \\
1.336\end{array}$ & $\begin{array}{c}0.00 \\
000 \\
000\end{array}$ & \\
\hline & $\begin{array}{l}5 \\
10 \\
10\end{array}$ & 1.5 & $\begin{array}{l}12 \\
12\end{array}$ & $\begin{array}{ll}3.5 & 2.5 \\
5.0 & \end{array}$ & 2.5 & 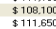 & 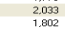 & 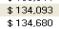 & $\begin{array}{ll}1.144 & 1.00 \\
1.445 & 1.00\end{array}$ & $\begin{array}{c}001 \\
000 \\
000\end{array}$ & 0 \\
\hline & $\begin{array}{c}5 \\
10 \\
10\end{array}$ & & ${ }_{12}^{12}$ & $\begin{array}{l}3.5 \\
5.0\end{array}$ & 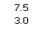 & 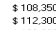 & $\begin{array}{l}2063 \\
1,909 \\
1,009\end{array}$ & 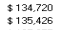 & $\begin{array}{l}1.451 \\
1.453 \\
1.000\end{array}$ & $\begin{array}{c}001 \\
000\end{array}$ & \\
\hline & $\begin{array}{c}6 \\
6 \\
6\end{array}$ & $\begin{array}{l}1.5 \\
1.5\end{array}$ & $\begin{array}{l}12 \\
12 \\
12\end{array}$ & $\begin{array}{l}5.0 \\
3.5 \\
3.5\end{array}$ & 1.00 & 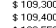 & $\begin{array}{l}2.2663 \\
2,059 \\
2\end{array}$ & 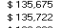 & $\begin{array}{l}1.461 \\
1.461 \\
1.000\end{array}$ & $\begin{array}{l}0.01 \\
0.01\end{array}$ & $\begin{array}{r}0 \\
172\end{array}$ \\
\hline & 5 & 1.5 & $\begin{array}{l}12 \\
12 \\
12\end{array}$ & $\begin{array}{ll}5.5 & 3.5 \\
3.5 & 3.5\end{array}-5$ & 10 & $\begin{array}{l}879.550 \\
9110.100\end{array}$ & 20.093 & 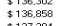 & $\begin{array}{l}1.168 \\
1.474 \\
1.00 \\
-1.00\end{array}$ & 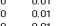 & ס \\
\hline & 8 & 1.5 & 12 & $\begin{array}{l}5.0 \\
5.0 \\
5.5\end{array}$ & 1.0 & 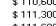 & $\begin{array}{l}2,299 \\
2,123\end{array}$ & 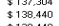 & $\begin{array}{ll}1.478 & 1.000 \\
1.491 & 1.00\end{array}$ & 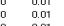 & $\begin{array}{c}172 \\
0\end{array}$ \\
\hline & $\frac{6}{5}$ & $\begin{array}{l}1.5 \\
3.5 \\
\end{array}$ & $\begin{array}{l}12 \\
12 \\
12\end{array}$ & $\begin{array}{ll}3.5 \\
3.5 & 3.5 \\
3.5 & 3.5\end{array}$ & ${ }_{1.0}^{0.0}$ & $\begin{array}{l}871,600 \\
311,4000\end{array}$ & 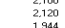 & 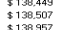 & $\begin{array}{l}1.491 \\
1.491 \\
1.000\end{array}$ & 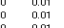 & 193 \\
\hline & ${ }_{6}^{10}$ & 1.5 & $\begin{array}{l}12 \\
12\end{array}$ & $\begin{array}{l}3.525 \\
350 \\
5.5\end{array}$ & & 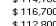 & 年 1917 & 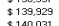 & $\begin{array}{l}1.502 \\
1.502 \\
1.000 \\
1.000\end{array}$ & 然 & 0 \\
\hline & $\begin{array}{l}5 \\
6 \\
6\end{array}$ & $\begin{array}{l}1.5 \\
3.5\end{array}$ & $\begin{array}{l}12 \\
12 \\
12\end{array}$ & $\begin{array}{ll}5.0 & 3.5 \\
5.5 & 2.5\end{array}$ & $\begin{aligned} & 1.0 \\
& 1.0 \\
& 1.0\end{aligned}$ & 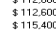 & $\begin{array}{l}2,130 \\
2,150 \\
1,956\end{array}$ & 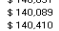 & $\begin{array}{ll}1.508 & 1.00 \\
1.511 & 1.00\end{array}$ & $\begin{array}{l}101 \\
0.01 \\
0.01\end{array}$ & 193 \\
\hline & $\begin{array}{c}5 \\
10 \\
10\end{array}$ & 3.5 & $\frac{12}{12}$ & $\begin{array}{ll}5.0 & 2.5 \\
3.5 & \end{array}$ & 75 & $\begin{array}{l}\$ 1115 \\
\$\end{array}$ & $\begin{array}{l}1,974 \\
1947\end{array}$ & 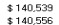 & $\begin{array}{lll}1.574 \\
1.08\end{array}$ & $\begin{array}{l}001 \\
\text { חס }\end{array}$ & 0 \\
\hline & $\begin{array}{r}6 \\
10\end{array}$ & $\begin{array}{l}1.5 \\
1.5\end{array}$ & $\begin{array}{l}12 \\
12\end{array}$ & $\begin{array}{ll}3.5 & 3.5 \\
5.0 & 2.5\end{array}$ & 2.5 & $\begin{array}{l}\$ 111,350 \\
\$ 117,900 \\
\$\end{array}$ & $\begin{array}{l}2,146 \\
\text { 2.1847 }\end{array}$ & 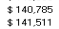 & $\begin{array}{lll}1.515 & 1.00 \\
1.519 & 1.00\end{array}$ & $\begin{array}{l}001 \\
0.000\end{array}$ & $\begin{array}{c}236 \\
0\end{array}$ \\
\hline & 帛 & $\begin{array}{l}3.5 \\
3.5 \\
3.5\end{array}$ & $\begin{array}{l}12 \\
12\end{array}$ & $\begin{array}{l}3.5 \\
5.0 \\
5.5 \\
2.5\end{array}$ & 1.0 & 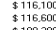 & $\begin{array}{l}2.204 \\
1,986\end{array}$ & 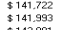 & $\begin{array}{l}1.526 \\
1.528 \\
1.000\end{array}$ & $\begin{array}{l}0.01 \\
0.01\end{array}$ & $\begin{array}{l}8 \\
5 \\
5\end{array}$ \\
\hline & $\frac{5}{10}$ & & $\begin{array}{l}5 \\
12 \\
12\end{array}$ & $\begin{array}{l}\begin{array}{l}3.5 \\
5.0\end{array} \\
5\end{array}$ & 7.5 & 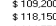 & $\begin{array}{l}2572 \\
1977\end{array}$ & 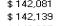 & $\begin{array}{lll}1.523 & 7.00 \\
1.5 .525 & 7.00\end{array}$ & 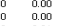 & \\
\hline & 8 & $\begin{array}{l}1.5 \\
5.0 \\
5.5\end{array}$ & $\begin{array}{l}12 \\
12\end{array}$ & $\begin{array}{l}5.0 \\
3.5 \\
3.5\end{array}$ & 2.5 & & $\begin{array}{l}2.1 \\
1,8 \\
1.8\end{array}$ & 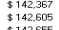 & $\begin{array}{ll}1.15322 \\
1.536 & 1.00 \\
1.00\end{array}$ & $\begin{array}{l}0.01 \\
0.01\end{array}$ & $\begin{aligned} 236 \\
0\end{aligned}$ \\
\hline & $\begin{array}{c}8 \\
10 \\
10\end{array}$ & & & & & & $\begin{array}{l}1,979 \\
1,877\end{array}$ & 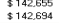 & & & $9^{9}$ \\
\hline
\end{tabular}

Fig. 12: The simulation results for standalone PVwind-hydrogen energy system

system performance. The HOMER simulation tool was used to optimize the sizes of different hardware components in the PV-wind-hydrogen system, taking into account the technical characteristics of system operation and minimizing total NPC of the system.

The simulation for this system was difficult due to the quantity of equipment involved to build the system and overall simulation takes around $4 \mathrm{~h}$ and $45 \mathrm{~min}$ to be accomplished. The optimization results for this analysis shown in Fig. 12. It illustrates that the most optimum results obtained for this system comprises of $6 \mathrm{~kW}$ of PV array, 2 unit of wind turbine, 12 units of batteries and $3.5 \mathrm{~kW}$ converter so as to generate the minimum COE, $\$ 1.33 \mathrm{kWh}^{-1}$. Although renewable sources (wind and PV) involved in the power generation, but no hydrogen was produced at all in this system.

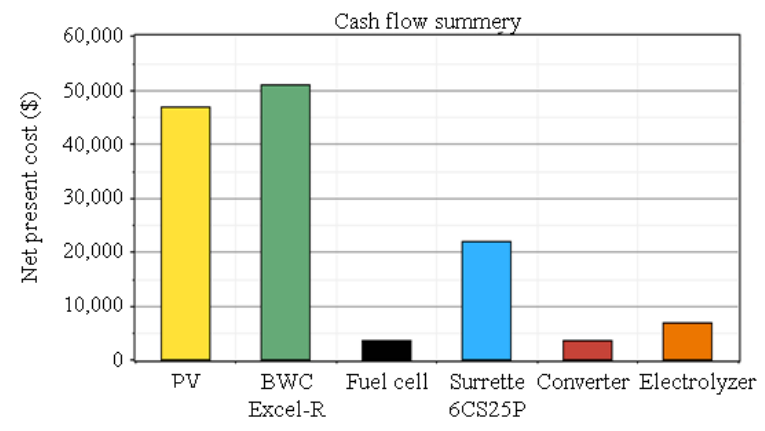

Fig. 13: Cost for component of standalone PV-windhydrogen system

Hence, the system that encompass of $6 \mathrm{~kW}$ of PV array, 2 unit of wind turbine, $1.5 \mathrm{~kW}$ of fuel cell, 12 unit of batteries, $3.5 \mathrm{~kW}$ converter as well as $2.5 \mathrm{~kW}$ of electrolyzer that generate fifteenth lowest $\mathrm{COE}$ at $\$ 1.44 / \mathrm{kWh}$ is being concentrated in this study due to the potential of hydrogen energy. The difference in $\mathrm{COE}$ value of both systems is not too much, so this system is also considered feasible.

In this PV-wind-hydrogen energy system, the PV array capacity was enlarge in relation to the one used in the PV-wind diesel system, from $2.5-6 \mathrm{~kW}$, in order to fully replace the diesel generator usage. The hydrogen tank is excluded from the system, as the storage tank is considered within the electrolyzer model and the hydrogen is supplied to the fuel cell directly from the electrolyzer.

The total capital costs and total NPC calculated for this system were $\$ 108,100$ and $\$ 134,093$ respectively (Table 3).

Wind turbine dominated the cost with $\$ 50,905$, followed by PV with $\$ 46,934$. Battery had contributed $\$ 22,001$ which was the third largest contributor for this system. Subsequently, electrolyzer, converter and fuel cell cost about $\$ 6,913, \$ 3,691$ and $\$ 3,648$, respectively. The allocation of each device can be seen clearly from Fig. 13.

The values related to the electricity production and load served by the system are summarize in Table 4 . The results of the simulation showed that the PV-windhydrogen system had a total annual electrical energy production of $17,414 \mathrm{kWh}$ year $^{-1}$. The biggest contributor is wind turbine with $9,435 \mathrm{kWh} \mathrm{year}^{-1}$ (56\%) followed by PV-array of 7,979 $\mathrm{kWh}_{\text {year }}{ }^{-1}$ (46\%). Fuel cell not contributes to the electricity generation at all.

The consumption of electricity about $60 \%$ $\left(7,264 \mathrm{kWh}\right.$ year $\left.^{-1}\right)$ goes to AC primary load served and $40 \%\left(4,931 \mathrm{kWh} \mathrm{year}^{-1}\right)$ goes to electrolyzer load. 
Energy Rec. J. 1 (1): 12-21, 2010

Table 3: Annualized cost for main components of the stand alone PV-wind-hydrogen system

\begin{tabular}{lccclrr}
\hline Component & Capital $(\$)$ & Replacement $(\$)$ & O and M (\$) & Fuel $(\$)$ & Salvage $(\$)$ & Total $(\$)$ \\
\hline PV & 42,000 & 11,225 & 0 & 0 & $-6,291$ & 46,934 \\
BWC Excel-R & 38,800 & 12,518 & 1,918 & 0 & $-2,330$ & 50,905 \\
Fuel cell & 4,500 & 0 & 0 & 0 & -852 & 3,648 \\
Surrette 6CS25P & 15,000 & 9,820 & 0 & 0 & $-2,819$ & 22,001 \\
Converter & 2,800 & 1,095 & 0 & 0 & -204 & -291 \\
Electrolyzer & 5,000 & 1,565 & 639 & 0 & $-12,787$ & 6,913 \\
System & 108,100 & 36,223 & 2,557 & & & 134,093 \\
\hline
\end{tabular}

Table 4: Operational characteristics of the stand alone PV-windhydrogen system

\begin{tabular}{llr}
\hline Annual electricity production & $\mathrm{kWh} \mathrm{year}^{-1}$ & Percent \\
\hline PV-array & 7,979 & 46.0 \\
Wind turbine & 9,435 & 54.0 \\
Fuel cell & 0 & 0.0 \\
Total production & 17,414 & 100.0 \\
Consumption & & \\
AC primary load served & 7,264 & 60.0 \\
Electrolyzer load & 4,931 & 40.0 \\
Total & 12,194 & 100.0 \\
Other & & \\
Excess electricity & 3,600 & 20.7 \\
Unmet electric load & 36.5 & 0.5 \\
Capacity shortage & 49.8 & 0.7 \\
\hline
\end{tabular}

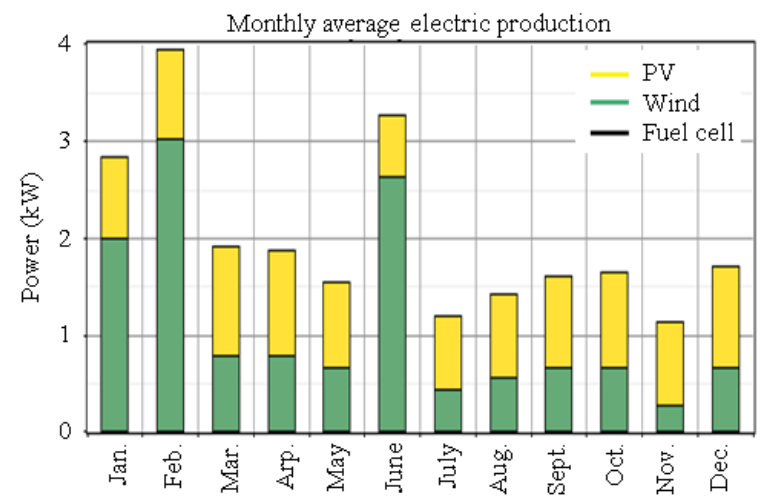

Fig. 14: Monthly electricity production trend of the stand alone PV-wind-hydrogen system

The difference of annual electricity production and consumption given the value of excess electricity for this system is $3,600 \mathrm{kWh}$ year $^{-1}(20.7 \%)$

The trend of monthly electricity production by these sources of energy is summarized in Fig. 13. The electricity from wind resources is higher in January, February and June.

The monthly hydrogen production from $2.5 \mathrm{~kW}$ electrolyzer can be seen in Fig. 15. The apparent months probable to produce hydrogen are January, February and June. The hydrogen production comes from potential wind energy in that particular month. The amount of yearly hydrogen production is $93.8 \mathrm{~kg} \mathrm{year}^{-1}$ make the average cost of hydrogen is $112 \mathrm{~kg}^{-1}$.

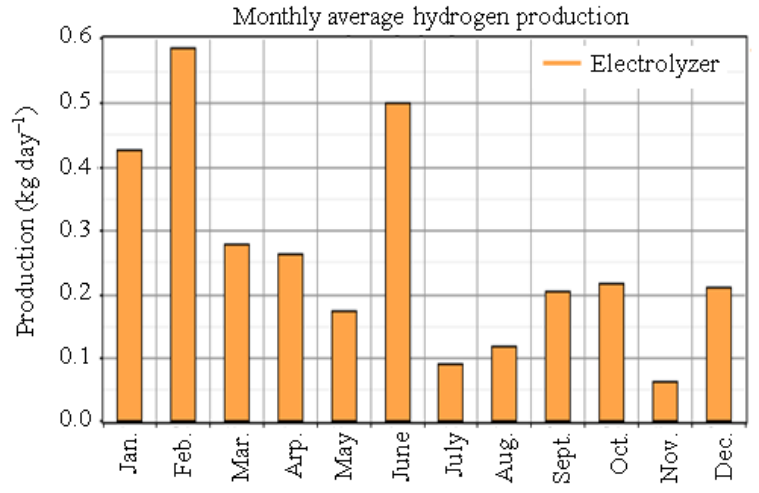

Fig. 15: Monthly hydrogen production of the stand alone PV-wind-hydrogen system

\begin{tabular}{|c|c|c|c|c|c|c|c|c|}
\hline \multicolumn{9}{|c|}{ 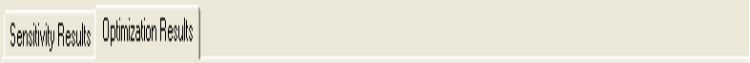 } \\
\hline \multicolumn{7}{|c|}{ 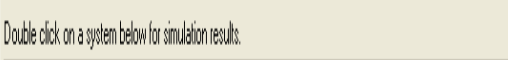 } & \multicolumn{2}{|l|}{ 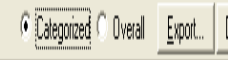 } \\
\hline 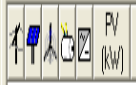 & & & 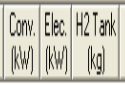 & \begin{tabular}{|l|} 
Gid \\
|kWI
\end{tabular} & $\begin{array}{l}\text { Inlibal } \\
\text { Capila }\end{array}$ & $\begin{array}{l}\text { Deeding } \\
\text { Corit(by) }\end{array}$ & 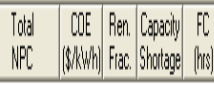 & \\
\hline & & & 35 & 1000 & $\$ 2000$ & 90 & $\$ 14,8001570000000$ & \\
\hline & & & 35 & 1000 & $\$ 9,000$ & 948 & 121,9320.235 $0.04 \quad 000$ & \\
\hline & & 1.5 & 3525 & 1000 & $\$ 1230$ & 1,012 & $\$ 26,2310.270 \quad 0.000000$ & 0 \\
\hline 㖶同 & & 1.5 & 3525 & 1000 & $\$ 19,300$ & $1,0,3$ & $132,4930.340 .0 .44 \quad 0.000$ & 0 \\
\hline A & 1 & & 35 & 1000 & $\$ 22,200$ & 1,021 & $\$ 35,510.370 \quad 0.560 .000$ & \\
\hline 种圈 & 1 & & 35 & 1000 & $\$ 29,200$ & 1,051 & $\$ 2,630 \quad 0.570 .040 \quad 0.000$ & \\
\hline $1 \mathrm{AO}$ & 1 & 1.5 & 3525 & 1000 & $\$ 31,000$ & 1,104 & $45,812 \quad 0.491 \quad 0.5 \quad 0.500$ & 0 \\
\hline 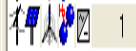 & 1 & 1.5 & 3525 & 1000 & 138700 & 1,134 & $853,980.5000 .680 .000$ & 0 \\
\hline
\end{tabular}

Fig. 16: The simulation results for grid connected PVwind-hydrogen energy system

Grid connected PV-wind-hydrogen system simulation: The simulation for this system took around $45 \mathrm{~min}$ to be accomplished. The optimization results for this analysis shown in Fig. 16. It illustrates that the most optimum results obtained for this system comprises of grid system 1000 and $3.5 \mathrm{~kW}$ converter so as to generate the minimum COE, $\$ 0.157 \mathrm{kWh}^{-1}$.

Hence, the system that encompass of $1 \mathrm{~kW}$ of $\mathrm{PV}$ array, 1 unit of wind turbine, $1.5 \mathrm{~kW}$ of fuel cell, $3.5 \mathrm{~kW}$ converter as well as $2.5 \mathrm{~kW}$ of electrolyzer that 
Energy Rec. J. 1 (1): 12-21, 2010

Table 5: Annualized cost for main components of the grid connected PV-wind-hydrogen system

\begin{tabular}{|c|c|c|c|c|c|c|}
\hline Component & Capital (\$) & Replacement (\$) & $\mathrm{O}$ and $\mathrm{M}(\$)$ & Fuel (\$) & Salvage (\$) & Total (\$) \\
\hline PV & 7,000 & 1,871 & 0 & 0 & $-1,048$ & 7,822 \\
\hline BWC Excel-R & 19,400 & 6,259 & 959 & 0 & $-1,165$ & 25,453 \\
\hline Fuel cell & 4,500 & 0 & 0 & 0 & -852 & 3,648 \\
\hline Grid & 0 & 0 & 5,670 & 0 & 0 & 5,670 \\
\hline Converter & 2,800 & 1,095 & 0 & 0 & -204 & 3,691 \\
\hline Electrolyzer & 5,000 & 1,565 & 639 & 0 & -291 & 6,913 \\
\hline System & 38,700 & 10,790 & 7,268 & 0 & $-3,561$ & 53,19 \\
\hline
\end{tabular}

Table 6: Operational characteristics of the grid connected PV-windhydrogen system

\begin{tabular}{llr}
\hline Annual electricity production & $\mathrm{kWh} \mathrm{year}^{-1}$ & Percent \\
\hline PV-array & 373 & 4.00 \\
Wind turbine & 4,718 & 45.00 \\
Fuel cell & 0 & 0.00 \\
Grid purchases & 5,460 & 52.00 \\
Total production & 10,550 & 100.00 \\
Consumption & & \\
DC primary load served & 7,300 & 77.00 \\
Electrolyzer load & 144 & 2.00 \\
Grid sales & 2,048 & 22.00 \\
Total & 9,492 & 100.00 \\
Other & & \\
Excess electricity & 11.4 & 0.11 \\
Unmet electric load & 0.00 & 0.00 \\
Capacity shortage & 0.00 & 0.00 \\
Renewable fraction & 48.3 & \\
\hline
\end{tabular}

Table 7: NPC and COE for all three systems

\begin{tabular}{lrl}
\hline & $\mathrm{COE}$ \\
System & $\mathrm{NPC}(\$)$ & $(\$ / \mathrm{kWh})$ \\
\hline PV-wind diesel energy system & 84,348 & 0.90 \\
Stan alone PV-wind-hydrogen energy system & 134,093 & 1.44 \\
Grid connected PV-wind-hydrogen energy system & 53,197 & 0.57 \\
\hline
\end{tabular}

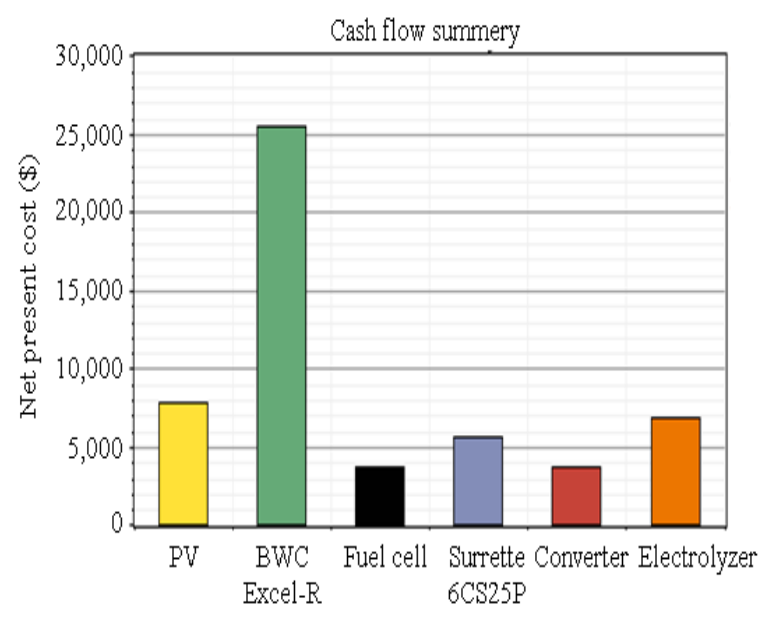

Fig. 17: Cost component of grid connected PV-windhydrogen system

generate eighth lowest $\mathrm{COE}$ at $\$ 0.57 \mathrm{kWh}^{-1}$ is being concentrated in this study due to the potential of hydrogen energy. The difference in COE value of both systems is too much, even though this system is also considered feasible. The battery is excluded from the system, as the system is connected to the grid.

The total capital costs and total NPC calculated for this system were $\$ 38,700$ and $\$ 53,197$ respectively (Table 5). Wind turbine dominated the cost with $\$ 25,453$, followed by PV-array with $\$ 7,822$. The grid cost $\$ 5,670$ which was the third largest contributor for this system. Subsequently, electrolyzer, converter and fuel cell cost about $\$ 6,913, \$ 3,691$ and $\$ 3,648$, respectively. The cost contribution of each device can be seen clearly from Fig. 17.

The value related to the electricity production and load served by the system are summarized in Table 6 . The results of the simulation showed that the PV-windhydrogen system had a total annual electrical energy production of $10,550 \mathrm{kWh}$ year $^{-1}$. The biggest contributor is grid system with $5,460 \mathrm{kWh} \mathrm{year}^{-1}(52 \%)$ and followed by wind turbine with $4,718 \mathrm{kWh} /$ year $(45 \%)$ and PV-array of $372 \mathrm{kWh} \mathrm{year}^{-1}(4 \%)$. Fuel cell not contributes to the electricity generation at all. The consumption of electricity about $77 \%(7,300 \mathrm{kWh}$ year $^{-1}$ ) goes to DC primary load served and 2\% (145 $\mathrm{kWh}$ year $^{-1}$ ) goes to electrolyzer load.

The electricity sells to grid accounted for $2,047 \mathrm{kWh}$ year $^{-1}(22 \%)$ as well. The difference of annual electricity production and consumption given the value of excess electricity for this system is $11.3 \mathrm{kWh} \mathrm{year}^{-1}(0.11 \%)$.

The trend of monthly electricity production by this source of energy is summarized in Fig. 18. The electricity from wind resources is higher in January, February and June and the rest mostly come out from grid.

The monthly hydrogen production from $2.5 \mathrm{~kW}$ electrolyzer can be seen in Fig. 19. The apparent months probable to produce hydrogen are January, February and June. The hydrogen production comes from potential wind energy in that particular month. The amount of yearly hydrogen production is $2.74 \mathrm{~kg} \mathrm{year}^{-1}$. whilst, the average cost of hydrogen is $1,517 \$ \mathrm{~kg}^{-1}$. 


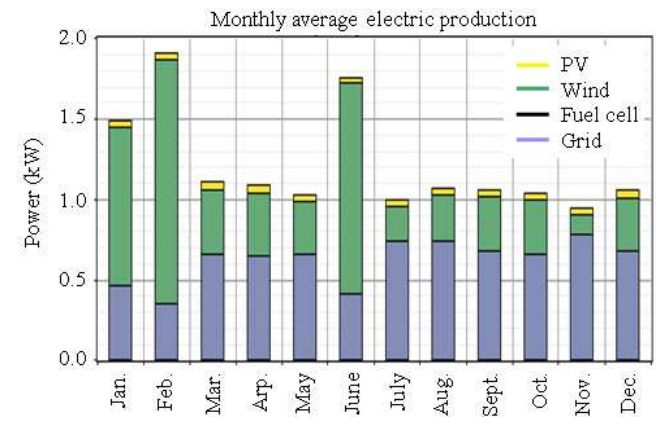

Fig. 18: Monthly electricity production trend of the grid connected PV-wind-hydrogen system

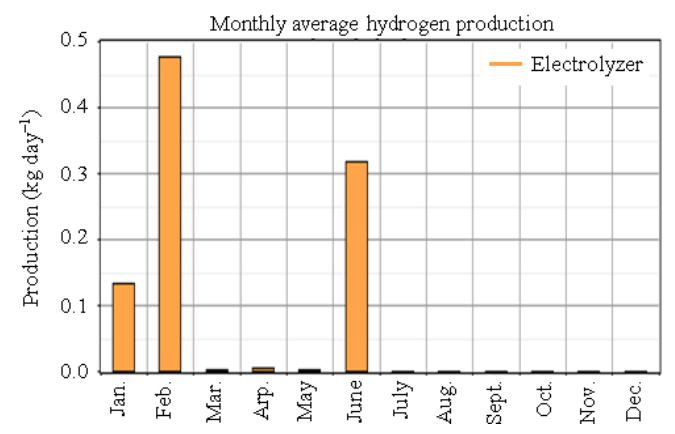

Fig. 19: Monthly hydrogen production for the grid connected PV-wind-hydrogen system

Comparison of all systems for the most cost effective system: Comparison of the entire systems that had been simulated by HOMER, it was found that the grid connected hybrid PV-wind-hydrogen energy system had the lowest total NPC and COE, \$53,197 and $\$ 0.57 \mathrm{kWh}^{-1}$ (Table 7) respectively that makes it the most cost effective system.

The stand alone PV-wind-hydrogen cannot defeat the grid connected PV-wind-hydrogen energy system in economical evaluation. This is probably due to the higher usage of expensive equipment among all the equipment involved. The grid systems that serve as battery eliminate the need for a battery backup for when the sun doesn't shine or the wind doesn't blow (Australian Government, 2009). In effect, the maintenance costs for the system will be less and make the COE cheaper.

\section{CONCLUSION}

The comparisons prove that grid connected PVwind-hydrogen energy system had the lowest total NPC and COE, which was $\$ 53,197$ and $\$ 0.57 \mathrm{kWh}^{-1}$ accordingly that makes it the most cost effective system and followed by PV-wind-diesel and stand alone PVwind-hydrogen system. Consequently, it is the most suitable system at lower cost to be developed in this area. However, the hydrogen energy is feasible by standalone system rather than grid system.

Hence, it can be concluded that the hydrogen-based system can become a favorable system without aid from the grid system and bring advantage in technical and economic point of view and also suitable to be applied in the coastal residential application as energy carrier if only the current cost of wind turbine and hydrogen system technology have been reduced to its minimum rate.

\section{ACKNOWLEDGMENT}

The acknowledgement goes to Engineering Science Department, University Malaysia Terengganu (UMT), Solar Energy Research (SERI), University Kebangsaan Malaysia (UKM) and Ministry of Science, Technology and Innovation of Malaysia (MOSTI) for providing supervision and financial support.

\section{REFERENCES}

Australian Government, 2009. Grid interactive systems. http://www.environment.gov.au/settlements/renew able/power/grid.html

Bergey Wind Power, 2007. Small wind turbines: For homes, business and off-grid. http://www.bergey.com

Dalton, G.J., D.A. Lockington and T.E. J. Baldock, 2009. Feasibility analysis of renewable energy supply options for a grid-connected large hotel. Renewable Energy, 34: 955-964. DOI: 10.1016/j.renene.2008.08.012

Demiroren, A. and U. Yilmaz, 2010. Analysis of change in electric energy cost with using renewable energy sources in Gokceada, Turkey: An island example. Renewable and Sustainable Energy Rev., 14: 323-333. DOI: 10.1016/j.rser.2009.06.030

Goh, W.C. and N.N. Barsoum, 2006. Balancing cost, operation and performance in integrated hydrogen hybrid energy system.

http://www.itee.uq.edu.au/ aupec/aupec06/htdocs/ content/pdf/3.pdf

Khan, M.J. and M.T. Iqbal, 2005. Pre-feasibility study of stand-alone hybrid energy systems for applications in Newfoundland. Renew. Energy, 30: 835-854. DOI:10.1016/j.renene.2004.09.001

Zoulias, E.I. and N. Lymberopoulos, 2007. Technoeconomic analysis of the integration of hydrogen energy technologies in renewable energy-based stand alone power systems. Renew. Energy, 32: 680-696. DOI: 10.1016/j.renene.2006.02.005 